\title{
HRM practices and MNC knowledge transfer
}

Dana B. Minbaeva

CKG WP 2/2004

March 2004 
CKG Working Paper No. 2/2004

March 2004

ISBN: 87-91506-17-4

Department of Management, Politics and Philosophy

Copenhagen Business School

The Center for Knowledge Governance

Blaagaardsgade $23 \mathrm{~B}$

DK-2200 Copenhagen N

Denmark

Phone +4538153630

Fax $\quad+4538153635$

E-mail: ckg.Ipf@cbs.dk

www.cbs.dk/ckg 


\title{
HRM practices and MNC knowledge transfer
}

\author{
Dana B. Minbaeva \\ Department of International Economics and Management \\ Copenhagen Business School, Denmark. \\ Howitzvej 60, 1 sal, DK2000 Copenhagen F, Denmark. \\ Tel. (45) 38152527. Fax (45) 38152500. Emaildm.int@cbs.dk
}

\begin{abstract}
The purpose of the paper is to determine and empirically examine the effect of human resource management practices on knowledge transfer within multinational corporations. It is suggested that the employment of human resource practices, which affect absorptive capacity of knowledge receivers and support organizational learning environment, is positively related to the degree of knowledge transfer to the subsidiary. Moreover, the higher degree of knowledge transfer is expected when human resource management practices are applied as an integrated system of interdependent practices. Hypotheses derived from these arguments are tested on the data from 92 subsidiaries of Danish multinational corporations located in 11 countries.
\end{abstract}

Key words: knowledge transfer, multintional corporations, HRM, complementarity

Acknowledgement: The author gratefully acknowledges the support of the MANDI project (Managing the Dynamic Interfaces between Knowledge and Culture) undertaken at the Copenhagen Business School. The author also would like to thank Professor Nicolai Juul Foss (Copenhagen Business School) for his helpful comments on the paper. 


\section{INTRODUCTION}

Empirical studies on internal knowledge transfer in multinational corporations (MNCs) have been focusing on how knowledge transfer within MNCs depends upon the characteristics of that knowledge (Zander and Kogut, 1995; Szulanski, 1996; Simonin, 1999), knowledge sources (Foss and Pedersen, 2002), knowledge senders (Lyles and Salk, 1996; Szulanski, 1996; Lane and Lubatkin, 1998; Gupta and Govindarajan, 2000; Lane, Salk and Lyles, 2001), knowledge receivers (Szulanski, 1996; Gupta and Govindarajan, 2000), their relationships (Szulanski, 1996; Simonin, 1999; Bresman, Birkinshaw and Nobel, 1999; Gupta and Govindarajan, 2000), etc. However, the referred literature has often paid very little attention to the idea that MNCs can institute various organizational policies and practices to facilitate knowledge transfer within MNCs. In the conclusions of those few studies that included organizational practices (see for example, Lane and Lubatkin, 1998; Gupta and Govindarajan, 2000), we often find calls for further research on "the learning capacities of organizational units", "more explicit description of the motivation and cooperative choices of the organizational individuals", "organizational mechanisms to facilitate knowledge acquisition", etc. Clearly, as a somewhat crude generalization, transfer of knowledge has been seldom consistently taken to be endogenous to organizational processes and arrangements (Foss and Pedersen, 2002).

On the other hand, researchers working in the field of human resource management (HRM) more than a decade ago called for the transformation of the HRM system and identified the support to the process of organizational learning as the key strategic task facing the HRM function in many MNC today (Pucik, 1988). Lado and Wilson (1994) suggest that HRM practices "can contribute to sustained competitive advantage through facilitating the development of competencies that are firm specific, produce complex social relationships, ... and generate organizational knowledge” (p. 699). 
Clearly, HRM practices and knowledge-related outcomes are associated but their link still misses some important aspects of the interpretation and empirical support. The paper aims to explore why this association exists and how various HRM practices influence knowledge-related outcomes. In particular, it is proposed that more extensive employment of HRM practices (those affecting knowledge receivers' ability and motivation, and supporting organizational learning environment) enhance knowledge transfer within MNCs. Furthermore, from the previous studies we have learned that HRM practices applied as a coherent system have greater effect on organizational outcomes than the sum of the individual effects from each practice alone (Ichniowski, Shaw and Prennushi, 1997). Therefore, it is also suggested that the impact of HRM practices on the degree of knowledge transfer is stronger when HRM practices are applied as a system of mutually reinforcing practices.

The novelty of the study is in bringing together two fields, which have not met very often: knowledge transfer and HRM. It is among the first attempts to examine empirically the role of HRM practices in the process of knowledge transfer within MNCs. The study differs from the existing limited work on HRM and knowledge transfer by introducing the wider range of HRM practices and looking at their system effect.

\section{THE KNOWLEDGE DRIVEN HRM PRACTICES}

Theoretical papers and numerous case studies have illustrated that knowledge management and HRM are linked. Developing the link further is a matter of penetrating the issues of what HRM practices and in which combinations do they matter for MNC knowledge transfer process. 


\section{What HRM practices?}

Managing human resources to achieve better knowledge-related outcomes means "retaining personnel, building their expertise into the organizational routines through learning processes, and establishing mechanisms for the distribution of benefits arising from the utilization of this expertise" (Kamoche and Mueller, 1998: 1036). To identify which HRM practices could be employed to help organizations to achieve knowledge-related outcomes, a brief review of representative case-based and existing empirical studies undertaken by scholars from different research fields (international HRM, innovation, strategy, international business, etc.) on the link between HRM practices and various knowledge-related outcomes is necessary. The purpose is to determine what HRM practices organizations could employ to enhance knowledge-related outcomes, otherwise known as knowledge-driven HRM practices.

Using an illustrative case study, Gupta and Singhal (1993) investigate how companies manage human resources to foster innovation and creativity. They conceptualize HRM practices along four dimensions:

- Human resource planning, which includes creating venture teams with a balanced skill-mix, recruiting the right people, and voluntary team assignment. This strategy analyzes and determines personnel needs in order to create effective innovation teams.

- Performance appraisal, which includes encouraging risk taking, demanding innovation, generating or adopting new tasks, peer evaluation, frequent evaluations, and auditing innovation processes. This strategy appraises individual and team performance so that there is a link between individual innovativeness and company profitability. Which tasks should be appraised and who should assess employees' performance are also taken into account. 
- Reward systems, which includes freedom to do research, freedom to fail, freedom to form teams, freedom to run businesses, balancing pay and pride, noticeable pay raises, dual career tracks, promoting from within, recognition rewards, and balancing team and individual rewards. This strategy uses rewards to motivate personnel to achieve an organization's goals of productivity, innovation and profitability.

- Career management, which includes empowering people, leading by example, and continued education. This strategy matches employees' long-term career goals with organizational goals through continuing education and training.

Source: Gupta and Singhal (1993), pp. 41-42

Recently, international business researchers have identified the role of HRM practices in the organizational learning as one subject of inquiry. For instance, Lane and Lubatkin (1998) look at the similarities and differences between the student and teacher firms in their study on relative absorptive capacity and interorganizational learning. Among other factors, the researchers consider compensation practices and find that a firm's ability to learn from another firm depends on the relative similarities of compensation policies in the student and teacher firms. Lyles and Salk (1996), and Lane, Salk and Lyles (2001) find training programs to be an important knowledge acquisition mechanism. They claim that, when properly organized, training programs are also important vehicles for establishing contacts between local and parent companies' employees, and thus promote collaboration and knowledge exchange. In Minbaeva et al. (2003) an effort is made to diverge from previous work on knowledge transfer within MNCs by integrating this stream more closely with the HRM-performance literature. The results of the study indicate that investments in the development of absorptive capacity of knowledge receivers through the extensive use of 
training, performance appraisal, performance-based compensation and internal communication contribute to MNCs knowledge transfer.

Similar discussions have been undertaken in innovation literature. Laursen and Foss (2003) investigate the link between new HRM practices and innovation performance, arguing that HRM practices are "most conducive to innovation performance when adopted, not in isolation, but as a system of mutually reinforcing practices" (p. 249). Applying principal component analysis, they identify two HRM systems that influence innovation performance. The first consists of HRM practices, which affect employees' ability to innovate. They are interdisciplinary workgroups, quality circles, systems for the collection of employee proposals, planned job rotation, delegation of responsibility, integration of functions, and performance-related pay. The second system is dominated by internal and external training. The overall conclusion is that "while the adoption of individual HRM practices may be expected to influence innovation performance positively, the adoption of a package of complementary HRM practices could be expected to affect innovation performance much more strongly" (Laursen and Foss, 2003: 257).

From the reviewed articles we learnt that there are certain knowledge-driven HRM practices, the extensive use of which enhances knowledge-related outcomes. We also learnt that the existing empirical work on the relations between HRM practices and knowledge-related outcomes has exclusively focused on the individual HRM practices and their isolated effect. That could become a serious limitation since HRM is defined as "a set of distinct but interrelated activities, functions, and processes that are directed at attracting, developing and maintaining (or disposing of) a firm's human resources" (Lado and Wilson, 1994: 701; emphasis added). 


\section{Which combinations of HRM practices?}

Once the question what HRM practices is addressed, the next step is to determine in which combination HRM practices matter to knowledge transfer.

The literature offers several choices. According to Wright and Boswell (2002) there are three alternatives to classify practices available to the researchers: conceptual (used for example Gardner et al., 2000), factor analytic (used for example Huselid, 1995) and cluster analysis (used for example Becker and Huselid, 1998). Conceptually it is be possible to identify HRM practices, which application enhances mediating variables (as it was recommended by Guest, 1997). Alternatively, the groups of HRM practices may be identified through some form of factor or principal component analysis. Generally speaking, factor analytic solution is useful when researchers wish to uncover the latent structure (dimensions) of a set of variables. In studies on HRM practices factor analysis has been used mainly for the following purposes: (1) to reduce a large number of independent variables, (2) to select a subset of independent variables from a larger set, based on which original variables have the highest correlations with the principal component factors, (3) to create a set of factors to be treated as uncorrelated variables as one approach to handling multicollinearity in such procedures as multiple regression, (4) to validate a scale or index by demonstrating that its constituent items load on the same factor, and to drop proposed scale items which cross-load on more than one factor. The final alternative is to use a cluster analysis. The cluster solution is possible when there is "a single most effective HRM system and a large group of firms have adopted it” (Delery, 1998: 301). The technique has been applied in several studies (see for example Arthur, 1992). Its proponents believe that when compared to factor analysis the cluster analysis does not assume linear relationships between practices, which may be crucial in some cases (Becker and Gerhart, 1996). However, the cluster technique was found to be less useful for testing theoretical frameworks (Delery, 1998). 
Despite of the variety of the statistical tools to classify the HRM practices, the literature recommends grouping of the practices to be derived from the theoretical rationales (MacDuffie, 1995; Youndt et al., 1996). It is not however often pursued and repeatedly "statistical sophistication appears to have been emphasized at the expense of theoretical rigor" (Guest, 1997: 263). In this paper, the following steps are taken to address this weakness. In the following section, first the mediating variables, which determine the relationships between HRM practices and knowledge transfer, are introduced. Then, the groups of HRM practices that produce those mediating variables are theoretically identified. In the analysis part of the paper, the grouping of HRM practices is justified through the factor analysis. Based on the grouping, two hypotheses on how HRM practices could influence knowledge transfer are derived. Finally, the issue of complementarity, within each of the identified groups of HRM practices and between them, is addressed.

\section{WHAT IS INSIDE OF THE "BLACK BOX"?}

There are at least two mediating variables that should have been considered when arguing for a link between HRM practices and knowledge transfer. They are knowledge receivers' ability and willingness to absorb knowledge, and the environment in which knowledge is determined, shared, interpret and used collectively.

The inability of knowledge receivers to recognize the value of new information, assimilate it, and apply it to commercial ends (low absorptive capacity) is one of the most often referred impediments to knowledge transfer (Cohen and Levinthal, 1990). It has been proposed in the knowledge transfer literature that absorptive capacity of the receiving unit is the most significant determinant of internal knowledge transfer in MNCs (Gupta and Govindarajan, 2000). Subsidiaries differ in their absorptive capacity, and this affects the level of internal knowledge transfer (Lyles and Salk, 1996; 
Szulanski, 1996, Mowery, Oxley and Silverman, 1996; Lane and Lubatkin, 1998; Gupta and Govindarajan, 2000; Lane, Salk and Lyles, 2001). Absorptive capacity has been conceptualized as being comprised of both employees' ability and motivation. Both aspects of absorptive capacity (ability and motivation) need to be present in order to optimally facilitate the absorption of knowledge from other parts of the MNC (Minbaeva et al, 2003).

Even subsidiaries with highly skilled and motivated employees will not be effective in knowledge transfer if subsidiaries are unsuccessful in building the infrastructure of learning and supporting learning environment. Knowledge transfer will be higher within certain organizational contexts where communication bridges between people and possibilities for dialogue across organizational hierarchy exist, where continuous learning opportunities are offered to employees, where systems to capture and share learning within the organization are established, etc. (Leavitt and March, 1988; Senge, 1990; Argyris and Schon, 1996).

The purpose of the following is to determine HRM practices, which enhance knowledge transfer by developing absorptive capacity of knowledge receivers and supporting organizational learning environment.

\section{Developing absorptive capacity of knowledge receivers}

Absorptive capacity has two elements: prior knowledge and intensity of effort (Cohen and Levinthal, 1990; Kim, 1998). "Prior knowledge base refers to existing individual units of knowledge available within the organization" (Kim, 1998: 271). Thus, employees' ability, their educational background and acquired job related skills represent the "prior related knowledge" which the organization needs to assimilate and use (Cohen and Levinthal, 1990). However, in order to perform effectively individuals should have both ability and willingness to absorb transferred knowledge. Indeed, few would question that "if individuals possess the prerequisite ability to learn 
... performance will likely be poor if motivation is low or absent" (Baldwin, Magjuka, and Loher, 1991: 52).

What HRM practices could enhance ability and motivation of knowledge receivers? As outlined by Huselid (1995), organizations, interested in achieving better individual ability, should employ those HRM practices that aim at acquiring, developing and retaining human capital. For example, an analysis of the competencies needed for different positions - together with an analysis of the firm's current pool of employee competencies - helps the organization specify the desired skills and knowledge. Staffing procedures aim to bring into vacant positions people with the identified skills and knowledge. There is extensive evidence that investment in employees' training enhances the human capital of the organization, which later results in a positive relationship between employee training and organizational performance (Delaney and Huselid, 1996; Koch and McGrath, 1996). In addition, performance appraisal (or performance management) systems provide employees with feedbacks on their performance and competencies, and give directions for enhancing their competencies to meet the needs of the organization.

"The effectiveness of even highly skilled employees will be limited if they are not motivated to perform" (Huselid, 1995: 637). HRM practices may influence individual performance by providing incentives that elicit appropriate behaviors. Such incentive systems may include performance-based compensation and the use of internal promotion systems that focus on employee merit and help employees to overcome invisible barriers to their career growth (Huselid, 1995). Indeed, while from an expectancy theory point of view it is the existence of a clear linkage between individual effort and reward that matters, from an equity theory (and organizational justice) perspective the main question is whether employees perceive that they receive the rewards that they are entitled to based on their contribution to the organization. Both perspectives would lead us to expect a positive 
relationship between performance-based compensation systems and employee effort. Promoting employees from within the firm is likely to provide a strong motivation for employees to work harder in order to be promoted (Pfeffer, 1994; Lepak and Snell, 1999). In addition, a philosophy of internal promotion indicates that a firm has decided to invest in its employees and is thus committed to them.

In sum, staffing, training, promotion, compensation and appraisal are expected to enhance knowledge transfer to the subsidiary through their affect on ability and motivation of knowledge receivers.

Hypothesis 1. The more the subsidiary adopts HRM practices, which affect absorptive capacity of knowledge receivers, the higher degree of knowledge transfer to the subsidiary is expected.

\section{Supporting learning environment}

Knowledge transfer is possible only when the close relationships between senders and receivers are established (Ghoshal and Bartlett, 1988; Gupta and Govindarajan, 2000). Rigid organizational boundaries impose high barriers, which impede knowledge flows at all levels of the MNC. By employing organizational practices that remove traditional boundaries, melt the bureaucratic structures and support learning, organizations may establish the environment that promotes knowledge transfer.

MNCs are multi-level entities, in which knowledge transfer takes place within at least two contexts - inter-organizational (between the focal subsidiary and the sister-subsidiaries, the focal subsidiary and the HQs) and intra-organizational (within the focal subsidiary, between its sub-units). Empirical researchers named frequency of communication in inter-organizational context as an important 
determinant of knowledge transfer process (Szulanski, 1996; Birkinshaw, Hood, and Jonsson, 1998; Bresman, Birkinshaw and Nobel, 1999; Gupta and Govindarajan, 2000). Szulanski (1996) argues that "a transfer of knowledge, especially when the knowledge transferred has a tacit components, may require numerous individual exchanges" (p. 32). Gupta and Govindarajan (2000) consider not only the existence of communication channels but also the richness of communication, captured as informality, openness, and density of communication. In particular, they find that corporate socialization mechanisms linking a focal subsidiary to the rest of MNC are positively associated with the knowledge transfer into that subsidiary.

There is also an increasing need for unobstructed knowledge transfer in intra-organizational context. The appearance of new forms of working practices such as flexible working practices reflects that need. Indeed, Hansen (1999) concludes that the lack of direct relations between people from different departments within the organization inhibits knowledge transfer. Crossing traditional organizational boundaries is important for effective use of obtained knowledge through common projects, decentralized and autonomous groups, flexible working arrangement, etc. In the empirical studies, flexibility was found to be associated with learning opportunities, organizational climate for innovation and development, higher capacities to absorb knowledge, etc. Lyles and Salk (1996) postulates that flexibility promotes knowledge transfer process "by encouraging greater receptivity of organizational members to new stimuli from the outside, by promoting collaboration and exchanges of information within the organization and by granting members greater latitude in altering activity patterns and ways of doing things to adopt to perceived changing needs an conditions" (p. 881-882). 
Overall, it is expected that corporate socialization mechanisms employed across MNCs units and flexible working practices employed within the subsidiary support learning environment and thereby increase knowledge transfer to the subsidiary.

Hypothesis 2. The more the subsidiary adopts HRM practices, which support learning environment, the higher degree of knowledge transfer to the subsidiary is expected.

\section{Evidence of complementarity?}

As mentioned, HRM practices are expected to have a stronger effect on the degree of knowledge transfer when they are applied as a system of mutually reinforcing practices. As defined in Milgrom and Roberts (1990, 1995), a system effect/complementarity occurs when "doing more of one thing increases the returns of doing more of the others" (p.181). Milgrom and Roberts $(1990,1995)$ does not assume an effect on performance from a simple pairwise relationship between two practices. Instead, they argue for multiple, complex interactions among several practices, reinforcing the effect of other practices in either a positive or negative direction. Overall, we should expect the full system effect of complementary practices to be larger than the sum of the marginal effects from adopting each practice individually (Ichniowski, Shaw and Prennushi, 1997).

In the HRM literature, the methods for testing complementarity vary substantially. However, a closer look indicates two simple alternatives - an additive approach vs. a multiplicative approach. Researchers who argue for the additive approach believe that its "desirable property" is that "the sum of normally distributed variable scores is still normally distributed, which is not try for the multiplicative product" (MacDuffie, 1995: 204). Others believe that "the hypothesis of synergies implies that we should test for interactive effects, as the synergy argument is that the effects of subsets of work practices are greater when they are implemented jointly" (Capelli and Neumark, 2001: 758). Capelli and Neumark agree with MacDuffie's counter argument that a multiplicative 
approach implies that if one work practice is not present the others have no effect. However, "as long as the main effects are entered along with the interactive effect, this criticism does not apply" (Capelli and Neumark, 2001: 758). In their argumentation Capelli and Neumark rely to large extent on findings of Ichniowski, Shaw and Prennushi (1997), who suggested "to examine the importance of sets of highly correlated and presumably complementary HRM practices, one must examine the effects of interactions among the practices" (Ichniowski, Shaw and Prennushi, 1997: 296)

However, researchers face a problem if they decide to test complementarity using the interaction terms. With a few HRM practices, there are often an insufficient number of degrees of freedom to test a full set of interaction terms among all HRM practices. For instance, in the data set of this paper I test the impact of 7 potentially complementary HRM practices on the degree of knowledge transfer. Adding two-way interactions (21 two-way interactions) while controlling for a main effect (7 individual practices) would result in 28 independent variables. Such analysis would require a larger sample and sufficient number of degrees of freedom (at least 140 observations). Some authors introduce higher-order interactions (see for example, MacDuffie, 1995). However, this solution is often criticized since the information provided by these effects is difficult to interpret.

A solution is to use a smaller set of interaction terms. The critiques warn that there may be "lack of theoretical motivation for the selection of combinations ... lack of clarity as to why certain combinations are selected over others ... (and the fact that) the authors consider only complementarities between several single practices" (Horgan, 2003: 124). But the critique is incongruous when combinations of HRM practices are defined conceptually (theoretically defined, reliability analysis) and/or empirically (factor analysis, cluster analysis). If grouping of HRM practices is done theoretically, the next step is to transform the individual variables into aggregate variables and then "explore complementarities between them by comparing the performance 
relationships of these singly and in various "system" combinations" (Whittington et al., 1999). Complementarities may also be explored within the groups of HRM practices (Delaney and Huselid, 1996).

Taking into consideration the above arguments the following approach for testing complementarity is chosen. In the previous section two groups of HRM practices were identified theoretically. The first group contains the practices influencing absorptive capacity of knowledge receivers. They are selection, promotion, training, compensation and appraisal. The second group consists of two practices supporting learning environment. They are corporate socialization mechanisms and flexible working practices. First, the grouping is to be verified through reliability test and factor analysis. Secondly, I introduce two-way interactions between individual HRM practices within each group and then check for complementarity between two groups of HRM practices. Theoretical expectations regarding complementarity are that the system effect of HRM practices on the dependent variable should be stronger than of the single practice. More detailed discussion on the expectations is found in the next section in which three hypotheses on complementarity are developed.

It is expected that staffing, promotion, training, compensation and appraisal, when applied as a system of mutually reinforcing practices, help MNCs to achieve higher outcomes, in terms of the degree of knowledge transfer to the subsidiary. Staffing (job analysis, recruitment and selection procedures) serves as the backbone for nearly all HRM activities of the organization. In the high performing organizations, staffing and promotion practices are closely connected since the organizations extensively use internal recruitment for all positions, including managerial, and prefer promotion from within to recruitment from outside. Placement decisions involving internal transfers, promotions, and demotions are also informed by the various selection approaches and by 
performance appraisals. Performance management is a process of identifying how closely the actual behavior matches the expectations derived from the previous job analysis. If the behavior of an individual departs significantly from the expectations (both positively and negatively), further actions should be taken to improve the actual behavior (training and transfer) and motivate for even better performance (compensation and benefits). The high performing organizations utilize the performance appraisal results to customize compensation programs for "must-keep" employees. Thus,

Hypothesis 3a. The higher degree of knowledge transfer is expected when HRM practices, which affect absorptive capacity of knowledge receivers, are applied as a system of mutually reinforcing practices.

The higher degree of knowledge transfer is expected when closer relationships between knowledge senders and receivers are established within both inter- and intra-organizational context. Ghoshal and Bartlett (1988) find that normative integration and communication within both inter- and intraorganizational contexts appeared to be positive to creation, adoption and diffusion of knowledge by MNCs' subsidiaries. The findings are supported by Gupta and Govindarajan (2000), who advocate a multi-level perspective in analyzing knowledge transfer. Overall, it is expected that complementarity among HRM practices, which support learning environment at inter- and intraorganizational levels, is to be positive.

Hypothesis 3b. The higher degree of knowledge transfer is expected when HRM practices, which support learning environment, are applied as a system of mutually reinforcing practices.

Previous research has shown that absorptive capacity will be higher when extensive intraorganizational communication is in place (Minbaeva et al., 2003). Knowledge transfer is expected 
to be higher within a certain organizational context due to promoting collaboration and social exchanges. Conceptually, this argument is in line with research on the social character of learning. According to the latter, it is important to focus on "the structure of communication between the external environment and the organization, as well as among the subunits of the organization, and also on the character and distribution of expertise within the organization" (Cohen and Levinthal, 1990: 131-132). Hence, it may be useful to consider the system effect between two groups of HRM practices influencing two determinants of knowledge transfer, i.e. affecting absorptive capacity and supporting a learning environment. Dealing with only one determinant is not likely to enhance knowledge transfer unless the other determinant is considered as well. Thus,

Hypothesis 3c. The higher degree of knowledge transfer is expected when HRM practices, which affect absorptive capacity of knowledge receivers and support learning environment, are applied as a system of mutually reinforcing practices.

\section{DATA AND METHOD}

The hypotheses are tested on a data set of the subsidiaries of Danish MNCs (headquartered in Denmark). For the construction of the data set the Hermes CD Direct from KOB (Kobmandstandes Oplysnings Bureau) was used. The database query was initiated by selecting the firms with headquarters in Denmark, and then limited to the ones, which had two or more subsidiaries abroad. This limitation was introduced as a result of the chosen operationalization of the degree of knowledge transfer. As will be discussed later this study has adopted the measure of knowledge transfer as a composite index of various types of knowledge transferred to the focal subsidiary from the headquarters and the sister subsidiaries. The procedure resulted in a list that was crosschecked with the Borsen 500 in order to ensure that the population was as complete and relevant as possible. 
Then, the number of the MNCs included in the sample was further limited to subsidiaries, which employ more than 30 employees. This limitation was necessary since small-scale companies in general and small subsidiaries in particular do not employ a big range of formal HRM practices (Miner and Crane, 1995).

Some of the Danish headquarters provided names and contacts at their subsidiaries; for other subsidiaries contacts were obtained from the foreign commercial sections of the Danish Embassies in the respective countries. The final data set consisted of 305 Danish subsidiaries located in Europe, Asia, and North America.

To test the hypotheses empirically, a questionnaire survey methodology was chosen. The new questionnaire was developed using a combination of prior related surveys (Gupta and Govindarajan, 2000; Szulanski, 1996; Simonin, 1999; Zander, 1991; Brewster et al., 2001) and findings from the pilot case studies (more on measures in the next section). The variables were captured through perceptual, self-report measures. To deal with the reliability of the perceptual measures, the interrate reliability test recommended by Gupta and Govindarajan (2000) was conducted prior to the analysis. The language of the questionnaire was English. Explanations of such terms as knowledge, knowledge transfer, and the degree of knowledge transfer were provided at the start of the questionnaire. The questionnaire was pre-tested. The purpose of the piloting stage was to try out the preliminary version on a small sample of (1) potential respondents, (2) people knowledgeable about the subject and (3) people ignorant of the subject. Managers interviewed in the pilot study were asked to complete the questionnaire and provide written feedback. The feedback from researchers and colleagues proved to be useful since they were very knowledgeable about the subject. Feedback from unknowledgeable pilot testers was also beneficial to estimate where the 
wording and sentences were too heavy for comprehension, where the language was incorrect, where the answering process was considered boring.

Selecting appropriate knowledgeable key informants was critical since the reliability of information about activities related to a subsidiary depended on whether the selected persons had the required knowledge. Since the survey had a lot of questions on HRM practices and employees' behavior, it was decided to address the questionnaire to a HRM manager/General Manager of the focal subsidiary. If the approached manager was unable to complete the survey, it was up to the individual to forward the questionnaire to another senior/middle level manager with sufficient knowledge regarding the themes of the study.

Due to the time and cost considerations, it was decided to use a web-based survey. The respondents were approached by the cover letter sent via email. The emails were as personalized as possible since personalization was reported to be "an important element in increasing the response rate " (Schaefer and Dillman, 1998: 380). Each email was addressed to one individual, had a name of that individual at the top and a name of the person through whom the contact was obtained (if applicable). In earlier studies it was found out that unsolicited questionnaires sent via email are unacceptable (Schaefer and Dillman, 1998). Instead, the cover letter/email explained the purpose of the survey, informed about the research process and analysis procedures, offered follow up reports and related working papers, and provided with straightforward directions about how to complete the questionnaire. The cover letter also contained a link to the questionnaire. The survey was put on the web page that could only be accessed through that link. This restricted unwanted answers and decreased the risk of potential error. An additional web page was established to back up the survey. The respondents were invited to visit the web page and read more about the survey subjects and the related themes. 
The resulting data set consisted of 92 subsidiaries (response rate of 30 per cent). The subsidiaries were located in USA, China, Germany, Sweden, UK, Russia, Poland, France, Sri Lanka, India, and Portugal. Descriptive data (mean values, standard deviation, minimum and maximum values) on all variables are provided in Table I.

- Insert Table I about here -

\section{MEASURES}

\section{Dependent variables}

The measure for the dependent variable was adopted from Gupta and Govindarajan (2000).

Degree of knowledge transfer (DoKT). The degree of knowledge transfer was defined at the beginning of the questionnaire as the extent to which the subsidiary's employees received knowledge, transferred to the subsidiary from the rest of MNC (headquarters and sister subsidiaries). Following Gupta and Govindarajan (2000) the data were collected on the following items: marketing know-how, distribution know-how, packaging design/technology, product designs, process designs, purchasing know-how and management systems and practices. Based on these, the respondents were asked to evaluate separately the degree of knowledge transfer from the sister subsidiaries and from the headquarters using a five-point Likert-type scale, where 1 indicates very low use of knowledge and 5 indicates substantial use of knowledge. Responses were averaged to yield a composite index reflecting the degree of knowledge transfer to the focal subsidiary from the rest of the MNC. Cronbach Alpha is 0.84 . 


\section{Independent variables}

In the literature the traditional measures for HRM practices do not correspond to the theoretical assumptions behind the knowledge-driven HRM practices (Keegan and Turner, 2001). Thus, some of the existing measures for high performance HRM practices were adopted from the previous studies and some of them were modified. The measures developed and described in Huselid (1995), Huselid, Jackson and Schuler (1997), Delaney and Huselid (1996) were used as main sources of inspiration. Additionally, scales were adopted from the Cranet survey on International Human Resource Management (1991, 1995, 1999). The measures were cross checked with the conclusions of theoretical papers, findings from the case studies and limited empirical work on the link between HRM and knowledge-related outcomes.

The respondents were asked to mark the number that best indicates the degree to which each statement describes HRM practices employed within their subsidiary. Respondents indicated this on a five-point Likert-type scales ranging from 1="never" to 5="always"

Staffing (Staffing). Staffing procedures aim to bring into vacant positions people with the previously identified skills and knowledge. The extent to which subsidiaries apply staffing procedures is measured through three items capturing the extent of competence-based job analysis, recruitment procedures, and variety of selection procedures used. Cronbach Alpha is 0.65 .

Training (Training). The extent of regular organized training was measured using an index comprised of three items: job-related skills training, regularity of training, and extent of degreeearnings programs supported by the organization. Cronbach Alpha is 0.71 .

Promotion (Promotion). The importance of merit-based promotion and internal transfer schemes is measured by an index comprised of two items. The first item measures whether promotion 
decisions are made of the basis of employees' previous performance and achievements. The second measures the extent of internal transfer taken place to allocate and retain talented people. Cronbach Alpha is 0.67 .

Compensation (Compensation). The degree of use of incentive compensation systems was measured using two items: performance-based compensation and extra recognition for superior performance. Cronbach Alpha is 0.79 .

Performance appraisal (Appraisal). One item is used to measure the extent to which the results of performance appraisal are used for developmental purposes.

Corporate socialization mechanisms (Inter). One item measures the existence of corporate socialization mechanisms across $\mathrm{MNC}$, which enhance inter-personal familiarity, personal affinity among employees from different subsidiaries.

Flexible working practices (Intra). One item measures the use of flexible working practices - such as flexitime, job sharing, part-time work - to accommodate best the individual working arrangements preferences.

\section{RESULTS}

The correlation coefficients were shown in Table II. There were high associations among HRM practices: 15 correlations out of a possible 21. Almost all HRM practices (except "inter" and "intra") were pairwise correlated. Some of the correlation coefficients indicated the possibility of multicolinearity (i.e. $r>0.5$ ). Thus, the previous choice of a factor analytic solution proved to be useful: it is a way to create a set of factors to be treated as uncorrelated variables as one approach to 
handling multicollinearity in regression. Following Huselid (1995), the independent variables were factor-analyzed using the principal component analysis. Factor loadings for each factor, eigenvalues and percentage of variance explained by each factor were reported in Table III.

- Insert Table II about here -

- Insert Table III about here -

The analysis had a confirmatory rather than exploratory nature. As expected, two factors with eigenvalues $>1$ emerged from the analysis. Factor 1 included a range of HRM practices employed to improve ability and motivation of knowledge receivers. Among them were "staffing", "training", “promotion”, “compensation” and "appraisal” (Cronbach Alpha 0.80). Factor 2 included corporate socialization mechanisms and flexible working practices employed to support a learning environment. Cronbach Alpha was much lower than for the first factor (0.30).

To test hypotheses 1 and 2, regression analysis on the degree of knowledge transfer was carried out. Model 1 in Table IV presented the results of the regression analysis when two factors (Factor 1 and 2) were entered simultaneously (as recommended by Huselid, 1995). The overall model was statistically significant $(\mathrm{p}<0.001)$ with R-square 0.187 (adjusted R-square 0.163 ). The simultaneous effect of "staffing", "training", "compensation", "promotion" and "appraisal” (Factor 1) on the degree of knowledge transfer was positive and highly significant $(\mathrm{p}<0.001)$. Hypothesis 1 is supported. The effect of Factor 2 ("inter" and "intra") on the dependent variable was in the expected direction but insignificant. It was anticipated since Cronbach Alpha of 0.30 for Factor 2 was too low to use the factor as a coherent construct.

- Insert Table IV about here - 
Models 2, 3, 4, 5 and 6 reported the results of the regression analyses carried out to test Hypotheses 3a, $3 \mathrm{~b}$ and 3c. At a first glance, the presence of complementarities was indicated by the presence of pairwise correlations among HRM practices. As expected, the correlations were generally positive and substantial (Table II). However, it is not enough. The logic of complementarity implies that "full system effects outweigh individual component effects" (Whittington et al., 1999: 585). Thus, to test for complementarity effect of HRM practices affecting absorptive capacity (hypothesis 3a) first "staffing”, "training", "compensation", "promotion" and "appraisal” were entered simultaneously (Model 2). Then, the impact of interactions between individual practices on knowledge transfer was tested while controlling for their main effect (Model 3). Both models were significant with $\mathrm{p}<0.05$ and R-square 0.183 (adjusted R-square 0.123 ) for Model 2 and R-square 0.340 (adjusted R-square 0.166) for Model 3. Among HRM practices affecting absorptive capacity, only training and compensation, and promotion and appraisal were mutually reinforcing. Indeed, the individual effects of compensation, promotion and appraisal were insignificant and the effect of training was only slightly significant $(\mathrm{p}<0.10)$. Only when applied together did these practices provide a significant influence on the degree of knowledge transfer. The interaction effects of "training x compensation" and "promotion x appraisal" were positive and significant at $\mathrm{p}<0.05$ and $\mathrm{p}<0.10$ accordingly.

The same tests were carried out for Hypothesis $3 \mathrm{~b}$ (Models 4 and 5) and Hypothesis 3c (Models 1 and 6). Neither of the hypotheses were confirmed. The individual effect of "inter" remained positive and significant even when the interaction "inter $\mathrm{x}$ intra" was entered. Hypothesis $3 \mathrm{~b}$ did not find any support. Interaction effect of Factor 1 and Factor 2 was insignificant. Positive and significant effect of Factor 1 remained at level $\mathrm{p}<0.001$. 
All tested models were significant. The highest explanatory power of 34 per cent was achieved in Model 3. However, the highest adjusted R-square (0.176) was reported in Model 6, which tested the complementarity effect of HRM practices both affecting absorptive capacity and supporting a learning environment. The adjusted R-square has the advantage over the normal R-square since it will not always increase when we add variables, but only increases if variables add significantly to the model.

\section{CONCLUDING REMARKS}

This paper aimed to determine and empirically examine HRM practices, the employment of which may help MNCs to overcome knowledge transfer barriers. From the previous research on MNC knowledge transfer it was concluded that among other things MNCs should develop employees' ability and motivation to absorb knowledge, and establish conditions for frequent communication and knowledge exchange among individuals. It was argued that MNCs can institute various HRM practices to overcome transfer barriers associated with the identified determinants and hence facilitate the degree of knowledge transfer. Two hypotheses were advanced based on the arguments that the employment of HRM practices, which affect knowledge receivers' ability and motivation, and support, positively related to the degree of knowledge transfer within MNCs. Note, the hypotheses were developed in a way that they assumed the simultaneous effect of HRM practices on the dependent variable and not the effect of individual practices. Such an assumption was recommended in the literature since it was found that HRM practices applied in combination have greater effect on organizational outcomes than the sum of the individual effects from each practice alone (Ichniowski, Shaw and Prennushi, 1997; Wright and Boswell, 2002). 
Factor analysis was used as a method of verifying the classification initially suggested by nonstatistical arguments or evidence. Results of the factor analysis indicated the existence of two groups of HRM practices hypothesized as being conducive to knowledge transfer - the first factor was marked by higher loadings on the HRM practices affecting ability and motivation of knowledge receivers (Factor 1). It contained staffing, training, compensation, promotion and appraisal. The second was marked by high loadings on the HRM practices supporting learning environment (Factor 2) and included corporate socialization mechanisms and flexible working practices. To further verify the classification the reliability analysis was conducted. Cronbach Alpha for Factor 1 was high and satisfactory (0.80), while for Factor 2 it was very low and did not justify the use of Factor 2 as a coherent constrict. The latter may be explained by the fact that not enough items were used to capture the HRM practices.

To test Hypotheses 1 and 2, the defined factors were entered as independent variables into the regression. The simultaneous effect of "staffing", "training", "promotion", "compensation" and "appraisal" (Factor 1) on the degree of knowledge transfer was positive and substantial. Hypothesis 1 was supported. Those organizations, which engage in the extensive staffing procedures (including examination of the competencies, extensive recruitment and selection procedures) are able to generate a pool of skilled external candidates, with a desired level of knowledge and skills, who in the future show the higher ability to absorb knowledge. Performance appraisal provides employees with feedback on their performance and competencies and offers direction for enhancing their competencies to meet the changing needs of the firm. An integrated part of most performance appraisal systems is also the establishment of objectives and targets for the self-development and training of employees. Training when organized as a systematic process helps to eliminate the skills deficiencies identified through performance appraisal. Promoting employees from within the firm is likely to provide a strong motivation for employees. Internal transfers as a variation of promotion 
activities aim at better allocating individual needs for growth and development. In addition to a learning experience, employees achieve higher commitment and involvement. Formation of performance-based compensation system that reward employees for the value of their job and their personal contribution to organizational performance is a strong incentive.

Contrary to expectations, the effect of corporate socialization mechanisms and flexible working practices was insignificant. Hypothesis 2 was not supported by the data.

The fact that HRM practices correlate with each other and end up in the same factor does not mean that they as a system contribute more to knowledge transfer than some of them individually. To test for complementarity it was recommended in the literature to use a multiplicative approach and test a full set of interactions while controlling for the main effect of individual practices. Due to the insufficient number of the degrees of freedom the testing was done separately for HRM practices affecting absorptive capacity of employees (Hypothesis 3a), for HRM practices supporting learning environment (hypothesis $3 \mathrm{~b}$ ) and for the whole set of HRM practices grouped into two factors (hypothesis 3c). The analysis indicated that complementarity exists for some of HRM practices affecting absorptive capacity. In particular, the interaction effects between "compensation" and "training", and "promotion" and "appraisal" were positive and significant. In each pair of the complementary practices one of the practices is related to improving the employees' knowledge related ability either through pointing at the deficiencies in performance and directing attention to the causes of deficiencies (appraisal) or providing employees with specific skills of helping them correct deficiencies in their performance (training). The other practice in the identified pairs of complementary practices aimed to recognize and reinforce the employees' behavior either by providing monetary (compensation) and non-monetary (promotion) incentives that elicit the appropriate behavior. These findings are in line with the previous findings of Minbaeva et al. 
(2003): managers can improve the absorptive capacity of their employees by applying specific HRM practices oriented towards employees' ability and employees' motivation. Moreover, to achieve better results those practices should be applied as a system.

The study has several limitations. First of all, the characteristics of knowledge receivers and learning environment are only two mediating variables to be considered when analyzing the link between HRM practices and knowledge transfer. Examining other black-boxed mediating variables, such as for example the senders' characteristics and the characteristics of the knowledge transferred, can extend the present model. Secondly, one of the challenges as pointed out by Huselid (1995) was the methodological problem confronting the survey-based research in general: survey response bias. The study of this type requires as broad sample as possible. Future research should also try to collect data from multiple respondents to minimize the risk of common method bias. The validity of the current data was limited due to the use of only one respondent per subsidiary, a weakness in most international research. However, it proved to be useful to test knowledge transfer measures for inter-rater reliability (recommended by Gupta and Govindarajan, 2000). Finally, one limitation of the statistical analysis is the use of control variables. Generally speaking, the proposed framework may benefit from including such control variables as size, industry, mode of entry, ownership, subsidiary age and previous experience (Birkinshaw, Hood, and Jonsson, 1998; Bresman, Birkinshaw, Nobel, 1999; Simonin, 1999; Gupta and Govindarajan, 2000). Degrees of freedom were not available to include all control variables at earlier stages of statistical analysis. Results of post-hoc analysis indicated no significant changes in either direction of the relationships or the regression coefficients after control variables were introduced. 
While this study makes a contribution to our understanding of the relationship between HRM practices and knowledge transfer in the $\mathrm{MNC}$, clearly, additional research is needed to further develop this link, which till now has been largely black-boxed. 


\section{REFERENCES}

Argyris, C. and Schon, D. (1996), Organizational Learning II, Addison-Wesley, Reading, MA

Arthur, J. (1992), The Link between Business Strategy and Industrial Relations Systems in American Steel Minimills, Industrial and Labor Relations Review, vol. 45: pp. 488-506

Arthur, J. (1994), Effects of Human Resource Systems on Manufacturing Performance and Turnover, Academy of Management Journal, vol. 37: pp. 670-687

Baldwin, T., Magjuka, R. and Loher, B. (1991), The Perils of Participation: Effects of Choice of Training on Trainee Motivation and Learning, Personnel Psychology, vol. 44: pp. 51-65.

Becker, B., Gerhart, B. (1996), The Impact of Human Resource Management on Organizational Performance: progress and prospects, Academy of Management Journal, vol. 39 no. 4: 779-801

Becker, B., Huselid, M. (1998), High Performance Work Systems and Firm Performance: a synthesis of research and managerial implications, Research in Personnel and Human Resources Management, vol. 16: 53-101

Birkinshaw, J., Hood, N. and Jonsson, S. (1998), Building Firm-Specific Advantages in Multinational Corporations: the role of subsidiary initiative, Strategic Management Journal, vol. 19: pp. 221-241

Bresman, H., Birkinshaw, J. and Nobel, R. (1999), Knowledge Transfer in International Acquisitions, Journal of International Business Studies, vol. 30 no. 3: pp.439 - 462 
Brewster, C., Communal, C., Farndale, E., Hegewisch, A., Johnson, G., and van Ommeren, J. (2001), The HR Healthcheck. Benchmarking HRM Practices across the UK and Europe, Report published by Cranfield University School of Management and Financial Times, Prentice Hall

Capelli, P. and Neumark, D. (2001), Do "High-Performance" Work Practices Improve Establishment-Level Outcomes? Industrial and Labor Relations Review, vol. 54 no. 4: 737-775

Cohen, W. and Levinthal, D. (1990), Absorptive Capacity: a new perspective on learning and innovation, Administrative Science Quarterly, vol. 35: pp. 128-152

Delaney, J., and Huselid, M. (1996), The Impact of Human Resource Management Practices on Perceptions of Organizational Performance, Academy of Management Journal, vol. 39 no. 4: pp. 949-969

Delery, J. (1998), Issues of Fit in Strategic Human Resource Management: implications for research, Human Resource Management Review, vol. 8 no. 3: pp. 289-309

Foss, N. and Pedersen, T. (2002), Transferring Knowledge in MNCs: the role of sources of subsidiary knowledge and organizational context, Journal of International Management, vol. 8: pp. $1-19$

Gardner T., Wright, P. and McMahan, G. (2000), Measurement error and estimates of the HR-firm performance relationship: further evidence and analysis, Personnel Psychology, vol. 53: pp.855-872

Ghoshal, S. and Bartlett, C. (1988), Creation, Adoption, and Diffusion of Innovations by Subsidiaries, Journal of International Business Studies, vol. 19 no. 3: pp.365-388

Guest, D. (1997). Human Resource Management and Performance: a review and research agenda, International Journal of Human Resource Management, vol. 8 no.3: pp. 263-276 
Gupta, A. and Govindarajan, V. (2000), Knowledge Flows within MNCs, Strategic Management Journal, vol. 21: pp. 473-496

Gupta, A. and Singhal, A. (1993), Managing human resources for innovation and creativity. Research Technology Management, vol. 36 no. 3: pp. 41-48

Hansen, M. (1999), The search-transfer problem: the role of weak ties in sharing knowledge across organization subunits, Administrative Science Quarterly, vol. 44: 82-111

Horgan, J. (2003), High Performance Human Resource Management in Ireland and the Netherlands: adoption and effectiveness, Doctoral dissertation, Rozenberg Publishers

Huselid, M. (1995), The Impact of Human Resource Management Practices on Turnover, Productivity, and Corporate Financial Performance, Academy of Management Journal, vol. 38 no.3: pp. $635-672$

Huselid, M., Jackson, S., Schuler, R. (1997), Technical and Strategic Human Resource Management Effectiveness as Determinants of Firm Performance, Academy of Management Journal, vol. 40 no. 1: pp. 171-188

Ichniowski, C., Shaw, K. and Prennushi, G. (1997), The Effects of Human Resource Management Practices on Productivity: a study of steel finishing lines, The American Economic Review, June: pp. 291-313

Kamoche, K., and Mueller, F. (1998), Human Resource Management and the AppropriationLearning Perspective. Human Relations, vol. 51 no. 8: pp. 1033-1060

Keegan, A. and Turner, R. (2001), Quantity versus Quality in Project-Based Learning Practices, Management Learning, vol. 32 no. 1: pp.77-99 
Kim, L. (1998), Crisis Construction and Organizational Learning: capability building in catching-up at Hyundai Motor, Organization Science, vol. 9 no. 4: pp. 506-521.

Koch, M. and McGrath, R. (1996), Improving labor productivity: human resource management policies do matter, Strategic Management Journal, vol. 17 no. 5: pp. 335-354.

Lado, A. and Wilson, M. (1994), Human Resource Systems and Sustained Competitive Advantage: a competency-based perspective, Academy of Management Review, vol. 19: pp. 699-727

Lane, P. and Lubatkin, M. (1998), Relative Absorptive Capacity and Interorganizational Learning, Strategic Management Journal, vol. 19: pp. 461-477

Lane, P., Salk, J. and Lyles, M. (2001), Absorptive Capacity, Learning, and Performance in International Joint Ventures, Strategic Management Journal, vol. 22 no. 12: pp. 1139-1161.

Laursen, K. and Foss, N. (2003), New HRM Practices, Complementarities, and the Impact on Innovation Performance, Cambridge Journal of Economics, vol. 27: pp. 243-263

Leavitt, B. and March, J. (1988), Organizational Learning, Annual Review of Sociology, vol. 14: pp. $319-340$

Lepak, D. and Snell, A. (1999), The Human Resource Architecture: toward a theory of human capital allocation and development, Academy of Management Review, vol. 24: pp. 31-48

Lyles, M. and Salk, J. (1996), Knowledge Acquisition from Foreign Parents in International Joint Ventures: an empirical examination in the Hungarian context, Journal of International Business Studies, Special Issue: pp. 877-903 
MacDuffie, J. (1995), Human Resource Bundles and Manufacturing Performance: flexible production systems in the world auto industry, Industrial \& Labor Relations Review, vol. 48 no. 2: pp. 197-221.

Milgrom, P. and Roberts, J. (1990), The Economics of Modern Manufacturing Technology, Strategy and Organization. American Economic Review, vol. 80: pp. 511-528

Milgrom, P. and Roberts, J. (1995), Complementarities and Fit: strategy, structure and organizational change in manufacturing, Journal of Accounting and Economics, vol. 19: 179-208

Minbaeva, D., Pedersen, T., Bjorkman, I., Fey, C., and Park, H. (2003), MNC Knowledge Transfer, Subsidiary Absorptive Capacity and Knowledge Transfer, Journal of International Business Studies, vol. 34: pp. 586-599

Miner, J. and Crane, D. (1995), Human Resource Management: the strategic perspective, HarperCollins College Publishers.

Mowery, D., Oxley, J., Silverman, B. (1996), Strategic Alliances and Interfirm Knowledge Transfer. Strategic Management Journal, Winter Special Issue, vol. 17: pp. 77-91

Pfeffer, J. (1994), Competitive Advantage through People: Unleashing the Power of the Work Force, Boston: Harvard Business Press.

Pucik, V. (1988), Strategic Alliances, Organizational Learning, and Competitive Advantage: the HRM agenda, Human Resource Management, vol. 27 no. 1: pp.77-93

Senge, P. (1990), The Fifth Discipline: the art and practice of the learning organization. Doubleday, New York 
Schaefer, D. and Dillman, D. (1998), Development of a Standard E-mail Methodology, Public Opinion Quarterly, vol. 62 no. 3: pp. 378

Simonin, B. (1999), Transfer of Marketing Know-How in International Strategic Alliances: an empirical investigation of the role and antecedents of knowledge ambiguity, Journal of International Business Studies, vol. 30 no. 3: pp. 463-490

Szulanski, G. (1996), Exploring Internal Stickiness: impediments to the transfer of best practice within the firm, Strategic Management Journal, vol. 17, Winter Special Issue: pp. 27-43

Whittington, R., Pettigrew, A., Peck, S., Fenton, E., Conyon, M. (1999), Change and Complementarities in the New Competitive Landscape: A European Panel Study, 1992-1996, Organization Science, vol. 10 no. 5: pp. 583-600.

Wright, P. and Boswell, W. (2002), Desegregating HRM: a review and synthesis of micro and macro human resource management research, Journal of Management, vol. 28, no. 3: 247-276 Youndt, M., Snell, S., Dean, J., Lepak, D. (1996), Human Resource Management, Manufacturing Strategy, and Firm Performance, Academy of Management Journal, vol. 39 no. 4: pp. 836-866 Zander, U. (1991), Exploiting a Technological Edge: voluntary and involuntary dissemination of technology, Institute of International Business, Stockholm

Zander, U. and Kogut, B. (1995), Knowledge and the Speed of the Transfer and Imitation of Organizational Capabilities, Organization Science, vol. 6 no. 1: pp. 76-92 
Table I. Descriptive statistics for all variables

\begin{tabular}{|c|c|c|c|c|c|}
\hline Variable & Label & Minimum & Maximum & Mean & Std. Deviation \\
\hline Degree of knowledge transfer & DoKT & 1.00 & 4.36 & 2.4922 & 0.83605 \\
\hline Staffing & Staffing & 1.00 & 5.00 & 3.2815 & 0.87039 \\
\hline Training & Training & 1.00 & 5.00 & 3.1259 & 0.90474 \\
\hline Promotion & Promotion & 1.00 & 5.00 & 3.4398 & 0.98587 \\
\hline Compensation & Compensation & 1.00 & 5.00 & 3.4944 & 0.98156 \\
\hline Performance appraisal & Appraisal & 1.00 & 5.00 & 3.0274 & 1.14228 \\
\hline Corporate socialization mechanisms & Inter & 1.00 & 5.00 & 2.3483 & 0.91826 \\
\hline Flexible working practices & Intra & 1.00 & 5.00 & 2.6579 & 1.22804 \\
\hline
\end{tabular}




\section{Table II. Correlation matrix}

\begin{tabular}{|c|c|c|c|c|c|c|c|c|c|}
\hline & & 1 & 2 & 3 & 4 & 5 & 6 & 7 & 8 \\
\hline 1. & DoKT & 1.00 & & & & & & & \\
\hline 2. & Staffing & 0.137 & 1.00 & & & & & & \\
\hline 3. & Training & 0.127 & $0.528 * * *$ & 1.00 & & & & & \\
\hline 4. & Promotion & $0.231^{*}$ & $0.467 * * *$ & $0.496^{* * *}$ & 1.00 & & & & \\
\hline 5. & Compensation & 0.169 & $0.514 * * *$ & $0.555 * * *$ & $0.406 * * *$ & 1.00 & & & \\
\hline 6. & Appraisal & $0.301 * *$ & $0.541 * * *$ & $0.314^{* *}$ & $0.377 * *$ & $0.426^{* * *}$ & 1.00 & & \\
\hline 7. & Inter & $0.194^{\dagger}$ & $0.304 * *$ & $0.274 * *$ & 0.134 & $0.249^{*}$ & 0.157 & 1.00 & \\
\hline 8. & Intra & 0.063 & 0.059 & 0.094 & 0.016 & 0.011 & -0.013 & 0.187 & 1.00 \\
\hline
\end{tabular}




\section{Table III. Factor loadings for independent variables}

Extraction Method: Principal Component Analysis.

$\begin{array}{llc}\text { Variables } & \text { Factor 1 } & \text { Factor 2 } \\ \text { Staffing } & \underline{0.816} & -0.127 \\ \text { Training } & \underline{0.796} & 0.095 \\ \text { Promotion } & \underline{0.765} & -0.048 \\ \text { Compensation } & \underline{0.762} & -0.144 \\ \text { Appraisal } & \underline{0.662} & -0.192 \\ \text { Inter } & 0.357 & \underline{0.613} \\ \text { Intra } & 0.100 & \underline{0.822} \\ \text { Initial eigenvalues } & 3.039 & 1.137 \\ \text { \% of variance } & 43.415 & 16.237\end{array}$


Table IV. Regression analysis.

\begin{tabular}{|c|c|c|c|c|c|c|c|c|c|c|c|c|}
\hline \multirow[t]{2}{*}{ Variables } & \multicolumn{2}{|l|}{ Model 1} & \multicolumn{2}{|l|}{ Model 2} & \multicolumn{2}{|c|}{ Model 3} & \multicolumn{2}{|l|}{ Model 4} & \multicolumn{2}{|l|}{ Model 5} & \multicolumn{2}{|l|}{ Model 6} \\
\hline & $\beta$ & s.e. & $\beta$ & s.e. & $\beta$ & s.e. & $\beta$ & s.e. & $\beta$ & s.e. & $\beta$ & s.e. \\
\hline Constant & $2.576 * * *$ & 0.70 & $1.437^{* * *}$ & 0.332 & 0.670 & 1.258 & $2.066^{* * *}$ & 0.243 & $1.763^{* * *}$ & 0.497 & $2.576 * * *$ & 0.069 \\
\hline Staffing & & & 0.041 & 0.121 & $1.836^{*}$ & 0.743 & & & & & & \\
\hline Training & & & $0.199^{\dagger}$ & 0.111 & -0.681 & 0.660 & & & & & & \\
\hline Promotion & & & -0.003 & 0.092 & 0.147 & 0.597 & & & & & & \\
\hline Compensation & & & 0.032 & 0.095 & 0.131 & 0.438 & & & & & & \\
\hline Appraisal & & & 0.095 & 0.076 & -0.728 & 0.512 & & & & & & \\
\hline Inter & & & & & & & $0.228^{* *}$ & 0.086 & $0.373^{\dagger}$ & 0.223 & & \\
\hline Intra & & & & & & & -0.003 & 0.060 & 0.108 & 0.169 & & \\
\hline Factor 1 & $0.272 * * *$ & 0.70 & & & & & & & & & $0.287 * * *$ & 0.070 \\
\hline Factor 2 & 0.061 & 0.70 & & & & & & & & & 0.060 & 0.070 \\
\hline Staffing $\mathrm{x}$ Training & & & & & -0.116 & 0.174 & & & & & & \\
\hline Staffing $\mathrm{x}$ Promotion & & & & & -0.038 & 0.155 & & & & & & \\
\hline Staffing x Compensation & & & & & -0.257 & 0.173 & & & & & & \\
\hline Staffing $x$ Appraisal & & & & & -0.093 & 0.136 & & & & & & \\
\hline Training x Promotion & & & & & -0.126 & 0.130 & & & & & & \\
\hline Training $\mathrm{x}$ Compensation & & & & & $0.329 *$ & 0.161 & & & & & & \\
\hline Training x Appraisal & & & & & 0.177 & 0.113 & & & & & & \\
\hline Promotion x Compensation & & & & & -0.044 & 0.149 & & & & & & \\
\hline Promotion x Appraisal & & & & & $0.199^{\dagger}$ & 0.114 & & & & & & \\
\hline Compensation x Appraisal & & & & & -0.064 & 0.134 & & & & & & \\
\hline Inter x Intra & & & & & & & & & -0.051 & 0.073 & & \\
\hline Factor $1 \times$ Factor 2 & & & & & & & & & & & -0.110 & 0.076 \\
\hline $\mathrm{F}$ value & $7.917^{* * *}$ & & $3.011 *$ & & $1.957^{*}$ & & $3.662 *$ & & $2.587^{\dagger}$ & & $6.062 * * *$ & \\
\hline R-square & 0.187 & & 0.183 & & 0.340 & & 0.094 & & 0.100 & & 0.211 & \\
\hline Adjusted R-square & 0.163 & & 0.123 & & 0.166 & & 0.068 & & 0.061 & & 0.176 & \\
\hline
\end{tabular}




\section{CKG - Working Papers \\ www.cbs.dk/ckg}

\section{3}

2003-1: Nicolai J. Foss, Kenneth Husted, Snejina Michailova, and Torben Pedersen: Governing Knowledge Processes: Theoretical Foundations and Research Opportunities.

2003-2: Yves Doz, Nicolai J. Foss, Stefanie Lenway, Marjorie Lyles, Silvia Massini, Thomas P. Murtha and Torben Pedersen: Future Frontiers in International Management Research: Innovation, Knowledge Creation, and Change in Multinational Companies.

2003-3: Snejina Michailova and Kate Hutchings: The Impact of In-Groups and OutGroups on Knowledge Sharing in Russia and China CKG Working Paper.

2003-4: Nicolai J. Foss and Torben Pedersen : The MNC as a Knowledge Structure: The Roles of Knowledge Sources and Organizational Instruments in MNC Knowledge Management CKG Working Paper.

2003-5: Kirsten Foss, Nicolai J. Foss and Xosé H. Vázquez-Vicente: “Tying the Manager's Hands": How Firms Can Make Credible Commitments That Make Opportunistic Managerial Intervention Less Likely CKG Working Paper.

2003-6: Marjorie Lyles, Torben Pedersen and Bent Petersen: Knowledge Gaps: The Case of Knowledge about Foreign Entry.

2003-7: Kirsten Foss and Nicolai J. Foss: The Limits to Designed Orders: Authority under “Distributed Knowledge" CKG Working Paper.

2003-8: Jens Gammelgaard and Torben Pedersen: Internal versus External Knowledge Sourcing of Subsidiaries - An Organizational Trade-Off.

2003-9: Kate Hutchings and Snejina Michailova: Facilitating Knowledge Sharing in Russian and Chinese Subsidiaries: The Importance of Groups and Personal Networks Accepted for publication in Journal of Knowledge Management.

2003-10: Volker Mahnke, Torben Pedersen and Markus Verzin: The impact of knowledge management on MNC subsidiary performance: the role of absorptive capacity CKG Working Paper. 
2003-11: Tomas Hellström and Kenneth Husted: Mapping Knowledge and Intellectual Capital in Academic Environments: A Focus Group Study Accepted for publication in Journal of Intellectual Capital CKG Working Paper.

2003-12: Nicolai J Foss: Cognition and Motivation in the Theory of the Firm: Interaction or "Never the Twain Shall Meet"? Accepted for publication in Journal des Economistes et des Etudes Humaines CKG Working Paper.

2003-13: Dana Minbaeva and Snejina Michailova: Knowledge transfer and expatriation practices in MNCs: The role of disseminative capacity.

2003-14: Christian Vintergaard and Kenneth Husted: Enhancing selective capacity through venture bases.

\section{4}

2004-1: Nicolai J. Foss: Knowledge and Organization in the Theory of the Multinational Corporation: Some Foundational Issues

2004-2: Dana B. Minbaeva: HRM practices and MNC knowledge transfer

2004-3: Bo Bernhard Nielsen and Snejina Michailova: Toward a phase-model of global knowledge management systems in multinational corporations

2004-4: Kirsten Foss \& Nicolai J Foss: The Next Step in the Evolution of the RBV: Integration with Transaction Cost Economics

2004-5: Teppo Felin \& Nicolai J. Foss: Methodological Individualism and the Organizational Capabilities Approach

2004-6: Jens Gammelgaard, Kenneth Husted, Snejina Michailova: Knowledge-sharing Behavior and Post-acquisition Integration Failure 